\title{
Peran Advokat dalam Mewujudkan Peradilan yang Berintegritas ${ }^{1}$
}

\author{
Hibnu Nugroho. \\ Universitas Jendral Soedirman Purwokerto \\ hibnunugroho@gmail.com
}

\begin{abstract}
The renewal of the law as well as renewal in legislation is also aimed at renewing the ethics and moral of law enforcement as the perpetrations, advocates as law enforcement officials have a position to realize the role of enforcement Legal integrity. As one of the sub-systems of law enforcement, advocates have the same position to realize the role of law enforcement who are integrity in carrying out their profession and acting professionally in participating in implementing legal reforms in Indonesian. Although the profession of advocate has a distinctive characteristic of self-reliance, it does not mean that advocates are unable to play a role in creating a free-to-corruption Indonesia. Therefore, this writing will focus on the discussion of how the participation of the Advocate in participating in creating a judicial integrity in Indonesia. The purpose of this writing is to map the role of advocates in realizing a legal justice integrity. The writing approach uses a conceptual normative approach. Collection of data using libraries from various legal literature. Data processing uses data triangulation. Advocates have a role that embodies the reform of the legal paradigm in Indonesia because the advocate profession is closely related to the law enforcement process from the level of investigation to in Kract (a fixed-strength legal ruling). To maximize the role of an advocate should be initiated from an advocate organization that encourages all its members to be real being an advocate of integrity, and quality is not merely a leading advocate. The implication of this writing is as an effort to encourage the advocate organization to uphold and create anti-corruption principles that include accountability, transparency, fairness, policy, and policy control to prevent External causes of corruption.
\end{abstract}

Keyword: Advocate role, judicial integrity, legal reform

\footnotetext{
${ }^{1}$ Disampaikan dalam Seminar Nasional "Peran Penegak Hukum dalam Pembaharuan Paradigma Penegak Hukum", Rabu, 15 November 2017, di Universitas Pancasakti Tegal.
} 


\begin{abstract}
Abstrak
Pembaharuan hukum selain sebagai pembaharuan dalam peraturan perundang-undangan juga ditujukan sebagai pembaharuan etika dan moral para penegak hukum sebagai pelaksananya, advokat sebagai penegak hukum mempunyai kedudukan mewujudkan peran sebagai penegak hukum berintegritas. Sebagai salah satu sub sistem penegak hukum, advokat mempunyai kedudukan yang sama untuk mewujudkan peran sebagai penegak hukum yang berintegritas dalam menjalankan profesinya serta bertindak profesional dalam ikut serta melaksanakan pembaharuan hukum di Indonesia. Walaupun dalam menjalankan profesinya advokat memiliki ciri yang khas berupa kemandirian namun demikian bukan berarti advokat tidak mampu untuk berperan dalam mewujudkan Indonesia yang bebas korupsi. Oleh sebab itu penulisan ini akan memfokuskan diri pada pembahasan bagaimanakah peran serta advokat dalam ikut serta mewujudkan peradilan yang berintegritas di Indonesia. Tujuan penulisan ini untuk memetakan peran advokat dalam mewujudkan peradilan hukum yang berintegritas. Pendekatan penulisan menggunakan pendekatan normatif konseptual. Pengumpulan data menggunakan kepustakaan dari berbagai literatur hukum. Pengolahan data menggunakan triangulasi data. Advokat memiliki peran yang yang mewujudkan pembaharuan paradigma hukum di Indonesia karena profesi advokat berkait erat dengan proses penegakan hukum dari tingkat penyidikan hingga in kract (putusan hukum berkekuatan tetap). Untuk memaksimalkan peran advokat harus dimulai dari organisasi advokat yang mendorong semua anggotanya untuk secara nyata menjadi advokat yang berintegritas, dan berkualitas bukan sekedar melahirkan advokat top. Implikasi penulisan ini adalah sebagai upaya mendorong organisasi advokat mampu memegang teguh dan mewujudkan prinsip-prinsip anti korupsi yang meliputi akuntabilitas, transparansi, kewajaran, kebijakan, dan kontrol kebijakan untuk mencegah faktor eksternal penyebab korupsi.
\end{abstract}

Keyword: Peran Advokat, Peradilan Berintegritas, Pembaharuan Hukum

\title{
A. Pendahuluan
}

Pembaharuan hukum merupakan sebuah keniscayaan bagi semua negara didunia, cepatnya perkembangan disemua sektor kehidupan mau tidak mau memaksa hadirnya regulasi yang mampu menampung aspirasi setiap penggunanya. Sebagaimana diketahui bahwa hukum merupakan suatu sistem yang dibuat oleh regulator untuk membatasi perilaku manusia agar perilaku tersebut dapat terkontrol, hukum adalah aspek terpenting dalam pelaksanaan rangkaian kekuasaan kelembagaan.Hukum mempunyai tugas untuk menjamin adanya kepastian hukum dalam masyarakat.

Hukum memiliki peran yang sangat strategis dalam memacu percepatan pambangunan suatu negara. Usaha ini tidak semata- mata dalam rangka memenuhi tuntutan pembangunan jangka pendek tetapi juga meliputi pembangunan menengah dan jangka panjang. Meskipun disadari, setiap saat 
hukum bisa berubah sesuai dengan kebutuhan masyarakat yang menghendakinya. Di negara perkembang seperti Indonesia pembaharuan hukum menjadi prioritas hal ini disebabkan disatu sisi negara hukum nasional ingin melepaskan diri dari hukum Belanda yang hingga saat ini masih dipergunakan pada bidang-bidang hukum tertentu hal ini dilakukan agar lahir ketentuan perundangan yang bercita rasa Indonesia dan dapat mengadopsi kepentingan masyarakakat secara nasional. Di sisi lain tentunya harus segera lahir peraturan bercita rasa nasional yang mampu mengadopsi kebutuhan hukum modern yang melaju cepat agar mampu melindungi kepentingan masyarakat global yang sifatnya tidak lagi berbatas wilayah (borderless world).

Pembaharuan ditujukan bukan semata-mata hanya kepada pembaharuan peraturan perundang-undangan saja, namun didalamnya terkandung pula pembaharuan etika dan moral para penegak hukum sebagai pelaksananya, karena bila pembaharuan hukum hanya ditujukan untuk memperbaharui peraturan semata maka tujuan utama pembaharuan hukum tidak akan pernah tercapai. Sebagai salah satu sub sistem penegak hukum, advokat mempunyai kedudukan yang sama untuk mewujudkan peran sebagai penegak hukum yang berintegritas dalam menjalankan profesinya serta bertindak profesional dalam ikut serta melaksanakan pembaharuan hukum di Indonesia. Walaupun dalam menjalankan profesinya advokat memiliki ciri yang khas berupa kemandirian namun demikian bukan berarti advokat tidak mampu untuk berperan dalam mewujudkan Indonesia yang bebas korupsi. Oleh sebab itu makalah ini akan memfokuskan diri pada pembahasan bagaimanakah peran serta advokat dalam ikut serta mewujudkan peradilan yang berintegritas di Indonesia.

\section{B. Peran Advokat dalam Peradilan Indonesia}

Penegakan Hukum (law enforcement) dalam arti luas mencakup kegiatan untuk melaksanakan dan menerapkan hukum serta melakukan tindakan 
hukum terhadap setiap pelanggaran atau penyimpangan hukum yang dilakukan oleh subjek hukum, baik melalui prosedur peradilan ataupun melalui prosedur arbitrase dan mekanisme penyelesaian sengketa lainnya (alternative desputes or conflicts resolution). Bahkan, dalam pengertian yang lebih luas lagi, kegiatan penegakan hukum mencakup pula segala aktifitas yang di- maksudkan agar hukum sebagai perangkat kaedah normatif yang mengatur dan mengikat para subjek hukum dalam segala aspek kehidupan bermasyarakat dan bernegara benar-benar ditaati dan sungguh-sungguh dijalankan sebagaimana mestinya. Dalam arti sempit, penegakan hukum itu menyangkut kegiatan penindakan terhadap setiap pelanggaran atau penyimpangan terhadap peraturan perundang-undangan, khususnya "yang lebih sempit lagi" melalui proses peradilan pidana yang melibatkan peran aparat kepolisian, kejaksaan, advokat atau pengacara, dan badan-badan peradilan. ${ }^{2}$

Prinsip negara hukum menuntut antara lain adanya jaminan kesederajatan bagi setiap orang dihadapan hukum (equality before the law). Oleh karena itu undang-undang dasar juga menentukan bahwa setiap orang berhak atas pengakuan, jaminan, perlindungan, dan kepastian hukum yang adil serta perlakuan yang sama dihadapan hukum. Dalam usaha mewujudkan prinsipprinsip negara hukum dalam kehidupan bermasyarakat dan bernegara, peran dan fungsi advokat sebagai profesi yang bebas, mandiri dan bertanggung jawab merupakan hal yang penting, disamping lembaga peradilan dan instansi penegak hukum seperti kepolisian dan kejaksaan.

Seseorang yang mempunyai kedudukan tertentu disebut sebagai pemegang peran (role occupant) ${ }^{3}$ dalam menjalankan peran maka terkandung unsur-unsur

\footnotetext{
2 Jimly Asshiddiqie, Peran Advokat dalam Penegakan Hukum, Bahan Orasi Hukum pada Acara “Pelantikan DPP IPHI Masa Bakti 2007 - 2012", Bandung, 19 Januari 2008.

${ }^{3}$ Soerjono Soekanto, Faktor-faktor Yang mempengaruhi penegakan Hukum, Jakarta: Raja Grafindo Persada, 2010, hlm. 13.
} 
peran yang ideal (ideal role), peranan yang seharusnya (expected role), dan Peranan yang sebenarnya dilakukan (actual role).Peranan yang sebenarnya dilakukan kadang- kadang juga dinamakan "role performance" atau "role playing". Dengan demikian dapat dipahami bahwa peranan yang ideal dan seharusnya datang dari pihak atau pihak-pihak lain, sedangkan yang dianggap oleh diri sendiri serta peranan yang sebenarnya dilakukan berasal dari diri sendiri.

Seorang advokat sebagai role occupant menjalankan ideal role dan expected role. Profesi Advokat selaku penegak hukum yang sejajar dengan instansi penegak hukum lainnya, oleh karena itu satu sama lainnya harus saling menghargai antara teman sejawat dan juga antara para penegak hukum lainnya. Oleh karena itu juga, setiap Advokat harus menjaga citra dan martabat kehormatan profesi, serta setia dan menjunjung tinggi Kode Etik dan Sumpah Profesi, yang pelaksanaannya diawasi oleh Dewan Kehormatan sebagai suatu lembaga yang eksistensinya telah dan harus diakui setiap Advokat tanpa melihat dari organisasi profesi yang mana ia berasal dan menjadi anggota, yang pada saat mengucapkan Sumpah Profesinya tersirat pengakuan dan kepatuhannya terhadap Kode Etik Advokat yang berlaku. Dengan demikian Kode Etik Advokat Indonesia adalah sebagai hukum tertinggi dalam menjalankan profesi, yang menjamin dan melindungi namun membebankan kewajiban kepada setiap Advokat untuk jujur dan bertanggung jawab dalam menjalankan profesinya baik kepada klien, pengadilan, negara atau masyarakat dan terutama kepada dirinya sendiri. Nilai-nilai ideal seorang advokat adalah bersifat satria, jujur dalam mempertahankan keadilan dan kebenaran yang dilandasi moral tinggi, luhur dan mulia serta mampu menjunjung tinggi hukum, UUD RI, kode etik profesinya dan sumpah jabatannya (Pasal 2 Kode Etik advokat). 
Sudikno Mertokesumo ${ }^{4}$ menyatakan, bahwa pengacara atau advokat kedudukannya subjektif karena ia ditunjuk oleh salah satu pihak untuk mewakilinya di persidangan dan penilaiannyapun sangat subyektif karena ia harus membela kepentingan kliennya. Akan tetapi perlu diingat bahwa fungsi pokok seorang pengacara adalah untuk membantu melancarkan penyelesaian perkara dengan menjunjung tinggi pancasila, hukum dan keadilan. Disamping itu juga sesuai dengan kode etik advokat bahwa advokat tidak harus mengutamakan kepentingan kliennya saja akan tetapi lebih pada mengutamakan tegaknya hukum, keadilan dan kebenaran.

Bertitik tolak dari hal tersebut maka peran advokat selaku penegak hukum menjadi sangat penting untuk menjadi salah satu unsur penegak hukum yang mampu berpartisipasi menjadi agen dalam pembaharuan hukum di Indonesia sehingga mampu melahirkan peradilan yang berintegritas.

Peran ini masih belum sepenuhnya dipahami atau bisa saja masih terabaikan oleh advokat sendiri, dalam fakta dilapangan masih banyak dijumpai bagaimana advokat hanya berkutat dalam pemikiran semata-mata untuk kepentingan klien.Dan parahnya justru advokat merendahkan martabat profesinya dengan menyediakan diri sebagai "kurir" antara klien dengan penegak hukum.Beberapa diantara oknum advokat tersebut bahkan telah menjalani pidana akibat keterlibatannya dalam kasus suap.

Advokat mempunyai kedudukan yang istimewa dalam penegakan hukum. Keistimewaan ini terlihat dari ruang lingkup pekerjaan yang terbentang dari hulu ke hilir (dari tahap penyidikan sampai pelaksanaan hukuman), berbeda dengan penegak hukum lain yang bersifat parsial saja. Bidang pekerjaan advokat adalah memberikan jasa hukum atau bantuan hukum bagi masyarakat yang membutuhkannya.Tentu saja pemberian bantuan hukum oleh advokat

${ }^{4}$ Mukti Arto, Mencari Keadilan (Kritik Solusi terhadap Praktik Peradilan Perdata di Indonesia), Yogyakarta: Pustaka Pelajar, 2010, hlm. 131-132. 
dalam kerangka yang lebih besar ditujukan untuk memenuhi tujuan hukum, memelihara keteraturan, penyeimbang berbagai kepentingan, kesejahteraan, dan kebahagiaan. ${ }^{5}$

Jika kita pandang dari kacamata sosiologi hukum, kita dapat mengasumsikan bahwa ada dua faktor yang paling menonjol yang mempengaruhi aparat penegak hukum dalam menegakkan hukum yaitu faktor internal dan eksternal.Adapun faktor internal yang berasal dari penegak hukum itu sendiri. Salah satu contoh, adanya kecenderungan dari aparat penegak hukum dalam menegakan hukum berpedoman pada Undang-Undang semata sehingga mengesampingkan nilai-nilai yang berkembang dalam masyarakat. Selanjutnya faktor eksternal yang berasal dari luar diri penegak hukum, misalnya ketika terjadi peristiwa hukum adanya kecenderungan masyarakat yang menyelesaikan dengan caranya sendiri seperti halnya penyuapan. ${ }^{6}$

Tindak pidana korupsi di Indonesia sudah meluas dalam masyarakat. Perkembangannya terus meningkat dari tahun ke tahun, baik dari jumlah kasus yang terjadi dan jumlah kerugian negara maupun dari segi kualitas tindak pidana yang dilakukan semakin sistematis serta lingkupnya yang memasuki seluruh aspek kehidupan masyarakat. Meningkatnya tindak pidana korupsi yang tidak terkendali akan membawa bencana tidak saja terhadap kehidupan perekonomian nasional tetapi juga pada kehidupan berbangsa dan bernegara pada umumnya. Tindak pidana korupsi yang meluas dan sistematis juga merupakan pelanggaran terhadap hak-hak sosial dan hak-hak ekonomi masyarakat, dan karena itu semua maka tindak pidana korupsi tidak dapat digolongkan sebagai kejahatan biasa melainkan telah menjadi suatu kejahatan

\footnotetext{
${ }^{5}$ Agus Raharjo, “Pendayagunaan Teknologi Informasi sebagai Upaya Meningkatkan Pengawasan Terhadap Bekerjanya Sistem Peradilan Pidana di Jawa Tengah", Jurnal Dinamika Hukum, Vol. 10 No. 3 September 2010.

${ }^{6}$ Mukti Arto, Op.Cit. hlm.133
} 
luar biasa.Begitu pun dalam upaya pemberantasannya tidak lagi dapat dilakukan secara biasa, tetapi dituntut cara-cara yang luar biasa.

Di dalam kode etik profesi advokat dengan jelas diatur dalam ketentuan Pasal 2 yaitu didalam mempertahankan keadilan haruslah berlandaskan sifat satria, jujur, luhur dan mulia serta mampu menjunjung tinggi hukum atas dasar inilah integritas seorang advokat harus terbentuk. Didalam penanganan perkara Pasal 7 kode etik advokat mengatur bahwa advokat tidak boleh berhubungan secara sendiri (pribadi) dengan hakim.Advokat bisa menghubungi hakim bersama-sama dengan advokat dari pihak lawan (dalam perkara perdata) atau Jaksa Penuntut Umum (perkara pidana).Advokat tidak dibenarkan mengajari dan atau mempengaruhi saksi- saksi yang diajukan oleh pihak lawan dalam perkara perdata atau oleh jaksa penuntut umum dalam perkara pidana.

Dalam menjalankan profesi, seorang advokat tidak boleh diidentikan dengan kliennya, namun demikian sering dijumpai dalam praktik ada advokat yang mendapat julukan "advokat hitam" hal ini disebabkan karena advokat tersebut sangat sering mendamping klien dalam kasus korupsi bahkan mega korupsi. Namun demikian sepanjang dalam menjalankan profesinya tetap berpegang teguh kepada kode etik profesi tentunya tidak menjadi masalah karena pada akhirnya waktu juga yang akan membuktikan sepak terjang advokat tersebut.

Tuntutan profesi yang digeluti oleh advokat menjadikan advokat sangat dekat seluk beluk bahkan carut marut dunia hukum, advokat sangat tahu dimana kelemahan dan sekaligus kelebihan serta celah- celah selama proses penegakan hukum, disisi lain hubungan emosional dengan klien sering membuat advokat bersikap tidak profesional yang berakibat dirinya tergelincir dalam pusaran perilaku koruptif. Yang lebih parah advokat sering dituding menjadi biang kerok lahiirnya peradilan yang tidak berintegritas. 
Indonesia Corruption Watch (ICW) pernah mencatat 6 advokat yang ditangkap oleh KPK akibat tersandung masalah suap. Namun dalam perkembangannya sudah lebih banyak lagi advokat yang terkena OTT oleh KPK maupun penegak hukum hukum lain. Peran aktif advokat dalam melakukan pencegahan dan pemberantasan terhadap tindak pidana korupsi dan ikut serta menciptakan sistem peradilan yang berintegritas dalam konteks advokat sebagai penegak hukum dapat dilakukan secara maksimal, tinggal kemauan, cara dan metodenya saja yang dapat dilakukan sebagai pilihan. Salah satu tindakan yang dapat dilakukan oleh advokat adalah dengan menanyakan sumber pembayaran lawyer fee-nya, bisa jadi Pengacara menerima pembayaran dari hasil korupsi, dan dalam derajat tertentu advokat dapat dikualifikasikan sebagai gatekeeper yang menjadi bagian rangkaian tindak pidana pencucian uang. Sebagaimana sudah menjadi rahasia umum, mendampingi perkara korupsi lawyer fee nya sangat tinggi dan akan menjadi lebih tinggi apabila dapat mengeliminir ancaman pidana yang dijatuhkan. Contoh lainnya adalah dengan tidak membiasakan diri mencari jalan agar dapat melakukan kolusi.

Dengan kedudukan sebagai satu-satunya sub penegak hukum dalam sistem peradilan pidana yang mandiri memang dirasa cukup berat manakala harus menolak lawyer fee yang menggiurkan disisi inilah seorang advokat dapat membuktikan apakah dirinya bisa tetap teguh berpegang pada sumpah jabatan yang telah diucapkannya atau lebih memilih apa yang manis untuk dirinya. Beberapa faktor penyebab goyahnya integritas adalah aspek perilaku individu, aspek lingkungan tempat individu bekerja atau bergaul dan aspek organisasi dimana individu tersebut bernaung.

Faktor penyebab individu kehilngan integritas pada umumnya timbul karena sifat serakah yang dimiliki pelaku, sehingga betapapun besar penghasilan yang diperoleh masih dirasakan tidak cukup untuk memenuhi 
kebutuhannya. Hal ini berkait dengan pilihan gaya hidup yang konsumtif, sehingga perpaduan antara gaya hidup konsumtif dan sifat serakah akan menghasilkan ketidak kokohan prinsip dalam menghadapi godaan. Ada banyak contoh dari para pelaku korupsi yang telah dijatuhi pidana yang dapat membuka pemikiran kita semua bahwa pendapatan besar dan kedudukan yang tinggi serta terhormat tidak mampu membendung keserakahan sikap yang berujung padahilangnya integritas.

Pada aspek lingkungan dimana individu bekerja atau berinteraksi, dalam lingkungan dimana advokat menjalankan profesi sudah menjadi rahasia umum perilaku yang lekat dalam katagori tidak berintegritas masih sering dijumpai.Asas peradilan cepat dan biaya ringan masih belum sepenuhnya dirasakan secara merata. Ada beberapa yang sudah menjalankan dengan baik namun masih banyak pula yang masih bersifat angin-angin, tergantung bagaimana pimpinan lembaga tersebut menjalankan komitemen integritasnya. Masih adanya pungutan-pungutan diluar yang seharusnya, sangat memerlukan pengawasan dari masyarakat, dalam menghadapi kondisi yang demikian maka advokat dapat ikut menjadi bagian melakukan pengawasan serta melaporkan kepada lembaga-lembaga terkait termasuk kepada KPK, hal ini akan menjadi salah satu cara ikut bertanggungjawab menciptakan lembaga peradilan yang berintegritas.

Seorang advokat bernaung pada organisasi induknya, organisasi tersebut mempunyai kewenangan penuh untuk menindak anggotanya yang melakukan pelanggaran baik pelanggaran kode etik maupun undang-undang. Organisasi advokat sudah saatnya bersikap konsisten terhadap anggota yang melakukan tindakan tidak terpuji sepertiperilaku yang tidak berinregritas.Didalam Undangundang advokat telah ditetapkan wadah tunggal advokat namun demikian dalam fakta dilapangan masih terdengar kabar adanya pihak-pihak 
yang mengklaim sebagai wadah yang paling sah. Dalam kondisi yang demikian bisa saja terjadi seorang advokat yang diberhentikan tidak dengan hormat disatu organisasi yang menaunginya kemudian dirinya menjadi kutu loncat dengan pindah ke organisasi lain, ironisnya organisasi lain tersebut dengan senang hati menerima yang bersangkutan. Akibat kondisi ini kedudukan profesi advokat sebagai officium nobiletentu terkontaminasi. Dari sisi sesama advokat hal ini tentu akan menjadi preseden buruk, advokat tidak lagi menghargai organisasinya karena apabila dirinya melanggar dan dipecat maka masih dimungkinkan pindah ke organisasi lain dengan mudah.

Komisi Pemberantasan Korupsi memperkenalkan adanya Sistem Integritas Nasional (SIN) di Indonesia, mengapa ?.Karena integritas adalah kunci dari segala hal, semakin tinggi integritas seseorang, maka kian tahan pula terhadap serangan virus bernama korupsi.Demikian pula sebaliknya, kian rendah integritas, maka virus tadisemakin mudah menyerang dan menggerogoti.Begitu penting peran integritas, sehingga tidak hanya wajib dimiliki individu, namun juga sistem dan lembaga. ${ }^{7}$

Sistem integritas nasional ini diibaratkan sebagai pilar yang dipergunakan untuk menopang sebuah bangunan.Agar bangunan tetap dapat kokoh berdiri maka diperlukan tiga unsur penti ng yaitu pondasi, pilar atau tiang penyangga dan atap.Analogi tersebut untuk menggambarkan, unsur pertama adalah pondasi, dalam SIN dianalogikan sebagai sebuah pondasi.Pondasi disini adalah berupa komitmen nasional dan nilai-nilai luhur yang dimiliki oleh bangsa Indonesia.Sedangkan tiang penyangganya terdiri atas sejumlah pilar yang merepresentasinya berbagai elemen dalam bernegara.Dan terakhir, atap, merupakan hasil akhir yang dicapai berupa integritas nasional.

7 Komisi Pemberantasan Korupsi, Jalan Berliku Memberantas Korupsi (Laporan Tahunan KPK tahun 2012), Jakarta: KPK, 2010, hlm. 22. 


\section{Simpulan}

Advokat memiliki peran yang yang sangat besar dalam ikut serta mewujudkan pembaharuan paradigma hukum di Indonesia. Khusunya mendorong lahirnya sistem peradilan yang berintegritas karena profesi advokat berkait erat dengan proses penegakan hukum dari tingkat penyidikan hingga in kract maka organisasi advokat harus mampu mendorong semua anggotanya untuk secara nyata menjadi advokat yang berintegritas, dan berkualitas bukan sekedar melahirkan advokat top. Hendaknya organisasi advokat mampu memegang teguh prinsip-prinsip anti korupsi yang meliputi akuntabilitas, transparansi, kewajaran, kebijakan, dan kontrol kebijakan untuk mencegah faktor eksternal penyebab korupsi.

\section{Daftar Pustaka}

Arto Mukti, Mencari Keadilan (Kritik Solusi terhadap Praktik Peradilan Perdata di Indonesia), Yogyakarta: Pustaka Pelajar, 2001.

Asshiddiqie Jimly, Peran advokat dalam penegakan hukum, Bahan Orasi Hukum pada acara "Pelantikan DPP IPHI Masa Bakti 2007 - 2012", 2008.

Komisi Pemberantasan Korupsi, Jalan Berliku memberantas Korupsi (Laporan Tahunan KPK tahun 2012), Jakarta: KPK, 2012.

Raharjo Agus, Pendayagunaan Teknologi Informasi sebagai Upaya Meningkatkan Pengawasan Terhadap Bekerjanya Sistem Peradilan Pidana di Jawa Tengah, Jurnal Dinamika Hukum Vol. 10 No. 3 September 2010.

Soekanto Soerjono, Faktor-faktor Yang mempengaruhi penegakan Hukum, Jakarta: Raja Grafindo Persada, 2002.

Undang Undang Republik Indonesia Nomor 30 Tahun 2002 Tentang Komisi Pemberantasan Korupsi. 